\title{
IZ IZVJEŠĆA O STANJU U PROSTORU GRADA SENJA I OPĆINE KARLOBAG
}

Stipe Mudrovčić

Zavod za prostorno uređenje

Ličko-senjske županije

Dr. Franje Tuđmana 4

HR 53000 Gospić
UDK: 656.1:711.73(497.5 Senj)

Pregledni članak

Ur.: 2017-03-03

Rad se prvenstveno temelji na Izvješćima o stanju u prostoru koji daju najzorniju ocjenu postojećeg stanja, analize prostornog razvoja i planiranje razvoja za naredno razdoblje. Riječ je o Izvješćima za grad Senj i općinu Karlobag. Autor naglašava u radu koji su temeljni problemi, ali i određene komparativne prednosti u planiranju promatranog područja u podvelebitskom kanalu. Tako je s pomoću ovakvih dokumenata moguće planirati i predvidjeti mogući razvoj koji se temelji na postojećim uvjetima.

Ključne riječi: Grad Senj, prostorno planiranje, stanje u prostoru, Općina Karlobag

\section{Uvod}

Izrada podloge za prostorno-planiranje jedan je od najsloženiji poslova upravnih tijela unutar hrvatskih županija. Može se kazati da Ličko-senjska županija tu nije izuzetak, štoviše riječ je o najzahtjevnijem području za planere u Hrvatskoj. Još 1997. godine u tadašnjoj objavljenoj Strategiji prostornog uređenja Republike Hrvatske piše da je promatrajući prostor posebna vrijednost sa tri znakovita svojstva: prostor je konačan, zadan i ograničen, prostor je neobnovljiv i prostor je djeljiv između većeg broja korisnika. ${ }^{1}$

O upotrebi i korištenju prostora odlučuje veliki broj subjekata, a ti subjekti imaju različite interese u korištenju prostora i različitu ekonomsku moć. Uzroci sukoba interesa su različiti i višeslojni pa imamo: sukob nastao suprostavljanjem-nadređenjem privatnog nad društvenim interesom, sukob nastao favoriziranjem vrijednosti kratkoročnih pred dugoročnim interesom,

${ }^{1}$ M. SALAJ, 1997, 16. 
sukob nastao zbog korištenja prostora kojije suprotan prirodnoj predodređenosti, kao i sukob vrijednosti ekonomskih efekata u korištenju prostora i vrijednosti koje proizlaze iz humanih nacionalnih ili ekonomskih gledanja na korištenje prostora.

Predmet prostornog planiranja su naročito korištenje zemljišta, tehnički infrastrukturni sustavi, mreža i sustav naselja i objekti gradskog standarda življenja.

Kako je u fazi oživotvorenja Plana najvažnija aktivnost trajno praćenje realizacije Plana, razvitka pojedinih pojava, uočavanje zapreka ili iznalaženje boljih prostornih rješenja kroz detaljnije planiranje na što treba uputiti u Izvješću.

Svrha Izvješća jest da stručnoj javnosti osigura podatke i stvaranje informacijske osnove (s grafičkim prikazima) te da kompletira informacijskopodatkovne osnove. Dosadašnja Izvješća o stanju u prostoru pisana su kako bi se udovoljilo formi i ne daju podatke o realizaciji plana, razvitku pojedinih pojava, uočavanju zapreka i iznalaženju boljih planskih rješenja. Stoga se u Planovima uočava neujednačenost i slaba kvaliteta kartografskih podloga, pa tako npr. za izradu karte namjene nisu korištene podloge iz šumsko-gospodarskih osnova i vidi se slaba suradnja s nadležnim institucijama.

Javna poduzeća, koja upravljaju infrastrukturnim sustavima, nemaju katastre svojih vodova i nisu uspostavile svoj GIS. Također, u Planovima i Izvješćima nije dovoljno naznačen značaj mora ni kao plovnog puta ni kao gospodarskog resursa. Turističke su pak zone planirane "iz rukava",bez pravih analiza potencijala i mogućnosti i bez pokušaja korištenja potencijala zapuštenih naselja uz more.

Zakonom o prostornom uređenju je propisana obveza izrade Izvješća za jedinice lokalne samouprave kao četverogodišnji dokument praćenja stanja u prostoru.

${ }^{2}$ Izvješće Grada Senja objavljeno je u Službenom glasniku Grada Senja. Za izradu ovog Izvješća korišteni su podatci Državnog zavoda za statistiku, Prostornog plana uređenja Grada Senja., Prostornog plana Ličko-senjske županije(važeće 4. liD), Grada Senja-jedinstvenog upravnog odjela, Ličko-senjske županije-Upravnog odjela za gospodarstvo, LSŽ-Upravnog odjela za društvene djelatnosti, LSŽ-Upravnog odjela za graditeljstvo i zaštitu prirode i okoliša i komunalno gospodarstvo te od Hrvatske elektroprivrede OPS. Izvješće općine Karlobag nije još službeno objavljeno. Za izradu ovog Izvješća korišteni su podatci iz Prostornog plana LSŽ-e, Prostornog plana uređenja općine Karlobag, Ličko-senjske županije-Upravnog odjela za gospodarstvo, LSŽUpravnog odjela za društvene djelatnosti, LSŽ-Upravnog odjela za graditeljstvo i zaštitu prirode i okoliša i komunalno gospodarstvo te od Hrvatske elektroprivrede OPS te od Hrvatskog zavoda za zapošljavanje Područna služba Gospić. (op. aut.) 
S obzirom na navedeno Grad Senj i Općina Karlobag izradili su svoja

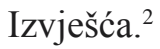

U Izvješću je, sukladno članku 5. Pravilnika sadržane sjedeće stavke prema kojima je i ovaj rad strukturian: polazišta, analiza i ocjena stanja, provedbe i trendova razvoja u prostoru, analiza provedbe dokumenata prostornoga uređenja i drugih dokumenata i prijedlozi za unaprjeđenje razvoja s osnovnim preporukama za naredno razdoblje.

Polazišta tako sadrže Osnovu i ciljeve izrade Izvješća što je već uvodno spomenuto. Zakonodavno-institucijski okvir izrade Izvješća proizlazi iz Zakona o prostornom uređenju (NN 153/13) i Pravilnika o sadržaju i obveznim prostornim pokazateljima Izvješća o stanju u prostoru (NN 48/14). ${ }^{3}$

Riječ je području koje zauzia veći dio istočne obale Kvarnera i velebitskog Podgorja, počevši od područje kraških obronaka Kapele i Senjskog bila na koje se nastavlja planinski masiv Velebita koji se proteže sve do obalne crte, a koja je na području ovih jedinica lokalne samouprave duljine gotovo sto kilometara. Obilježja područja Grada Senja i Općine Karlobag jesu oštro naglašen planinski okvir koji se bez prijelaznih zona, izravno približava moru i Kvarnerskom arhipelagu, dok masiv Velebita povezuje Senj i Karlobag koji je u cijelosti u Parku prirode Velebit gotovo u jednu cjelinu. Osnovna karakteristika senjskog i karlobaškog područja: na neplodnom krškom podgorskom kraju je rijetka naseljenost. U ovom surovom i ogoljenom kraju nema mnogo pitomih detalja.

Kroz povijest senjska luka i maritimne veze s otocima davale su senjskom području vrlo važan političko-ekonomski značaj. Razvijene veze između obalnog područja, u kojem dominira Senj i amfiteatralnog kontinentalnog zaleđa koje gravitira obalnom području, osigurale su Senju dobar makrogeografski položaj, te je zahvaljujući tome uspjevao tijekom povijesti održati izvjesnu koheziju u postojećoj ekonomskoj i socijalnoj strukturi svog područja. ${ }^{4}$ Naselje Karlobag kao općinsko sjedište izgubilo je u posljednje vrijeme svoju maritimnu vezu s otocima. Općenito je slaba dužobalna maritimna komunikacija Velebitskom kanalom iako bi bila turistički atraktivna. ${ }^{5} \mathrm{U}$ nastavku rada slijede analize stanja i dokumenata iz izvješća o stanju u prostoru ovih dviju upravnih jedinica.

\footnotetext{
${ }^{3}$ M. SALAJ, 1997, 17.

${ }^{4}$ Izvješće o stanju u prostoru Grada Senja, 2016.

${ }^{5}$ Izvješće o stanju u prostoru općine Karlobag (neobjavljeno), 2015, 1-61. Ovaj dokument se nalazi u Zavodu za prostorno planiranje Ličko-senjske županije.
} 
2. Analiza i ocjena stanja, provedbe i trendova prostornog razvoja

\section{Prostorna struktura korištenja i namjene površina Grada Senja i Općine Karlobag}

Struktura korištenja površina i zemljišta u Gradu Senju i Općini Karlobag je slična, s tim da od ukupne površine Grada Senja (od 663 km²) najviše zauzimaju šume (oko 64\%), zatim ostale šumske i pašnjačke površine (27\%), poljoprivredne površine zauzimaju svega 5\%, građevinske čine ispod 1,5\%, a od ukupne površine Općine Karlobag (od oko 287 km²) šumske površine zauzimaju oko 62\%, ostale šumske površine (kamenjari, pašnjaci makija) 37\%, dok su poljoprivredne površine minorne (oko $0,6 \%$ ), a građevinske površine su također ispod $1,5 \%$ površine Općine.

Grad Senj ima 27 naselja, od toga su Velike Brisnice bez stanovnika, dok Općina Karlobag ima 14 naselja, od čega tri bez stanovnika (Došen Dabar, Crni Dabar i Ravni Dabar), a naselja Konjsko i Staništa imaju ispod 10 stanovnika. Na prostoru Grada Senja i Općine Karlobag jedina naselja s urbanim obilježjima su Senj i Karlobag, dok na tih sto kilometara obalne crte svega par naselja, među kojima i sjedište Općine Karlobag, imaju tek oko petsto stanovnika. Prostor Podgorja je uglavnom pust i nenaseljen.

\section{Gospodarske djelatnosti, turizam, sport i rekreacija}

Cijeli prostor Podgorja je zaštićen i kao Park prirode i kao Zaštićeni obalni pojas, a sve turističke i gospodarske zone u tom prostoru moraju biti određene Prostornim planom Županije, a sve njihove promjene rješavaju se Izmjenama i dopunama PPŽ-a.

Već je u niz navrata spominjana činjenica o prostoru s malim površinama pogodnim za gradnju, pa za realizaciju velikih turističkih zona treba "razvaliti" pola Velebita.

Atraktivna i očuvana priroda na području cijelog Podgorja, te gotovo netaknuti ruralni sklop, omogućavaju kreiranje turističkog proizvoda kakvog europsko turističko tržište sve više traži.

Sada su planirane velike turističke zone teško ostvarive zbog imovinskopravnih odnosa, rješavanja infrastrukture, a postaju i predmetom sukoba, pa su, kako je to iz tabele vidljivo i ostale neizgrađene i pitanje je vremena kad će biti brisane iz prostorno-planske dokumentacije kao neostvarive . 


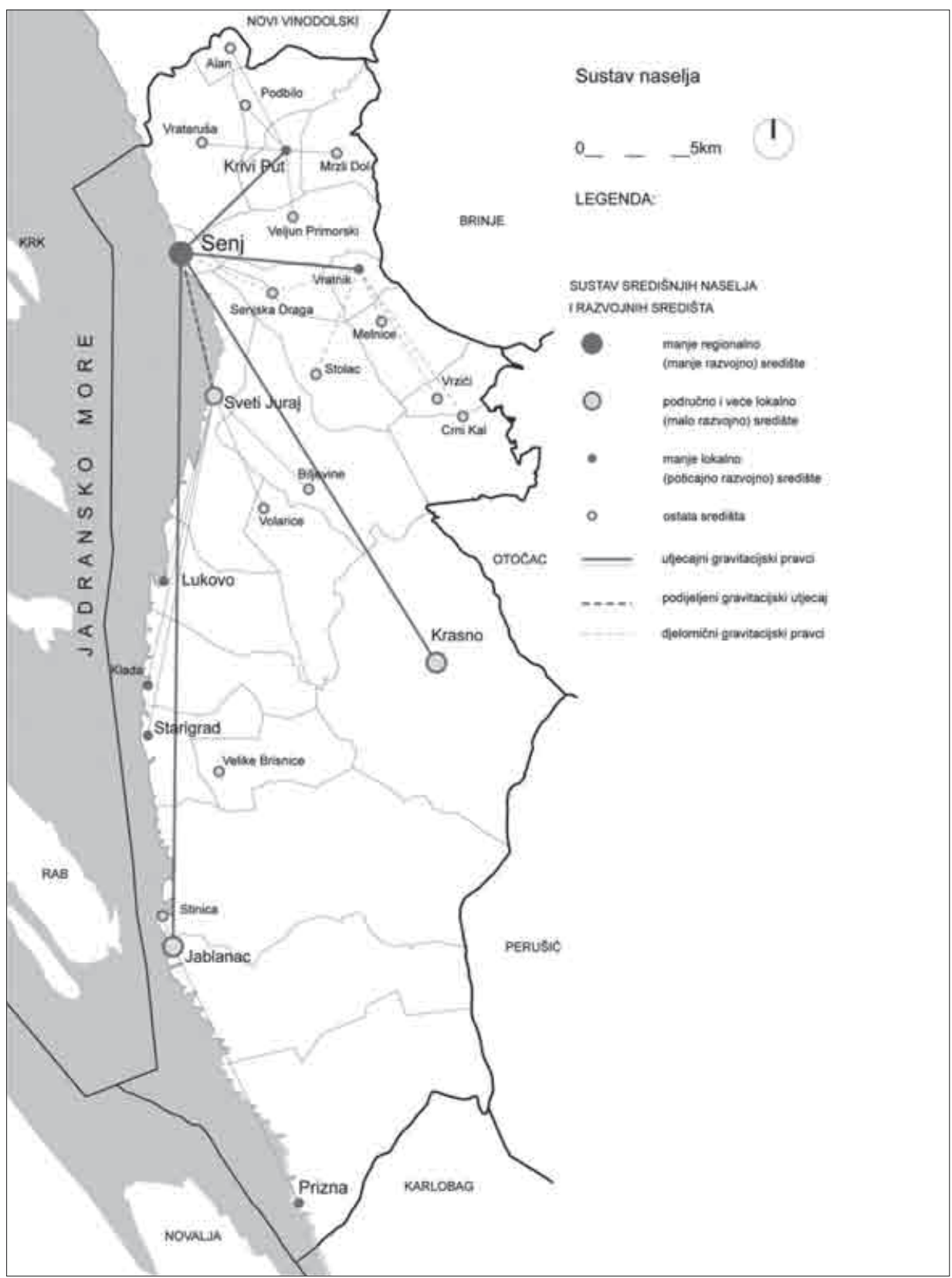

Karta 1. Sustav naselja Grada Senja, izvor: Službeni glasnik Grada Senja, br.1. od 26. veljače 2016, 35. 


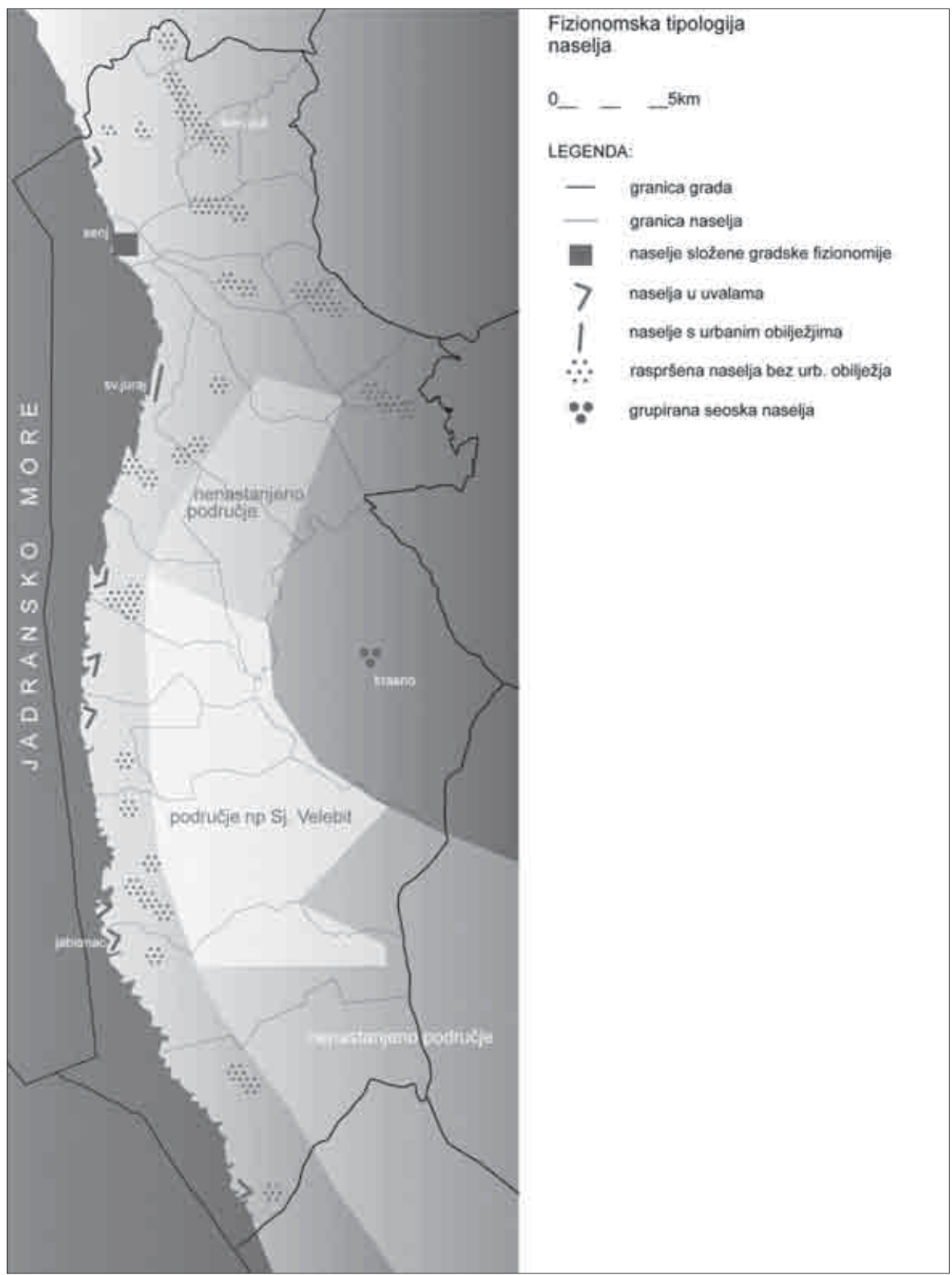

Karta 2. Grad Senj - tipologija naselja, izvor: Službeni glasnik Grada Senja, br.1. od 26. veljače 2016, 38 . 


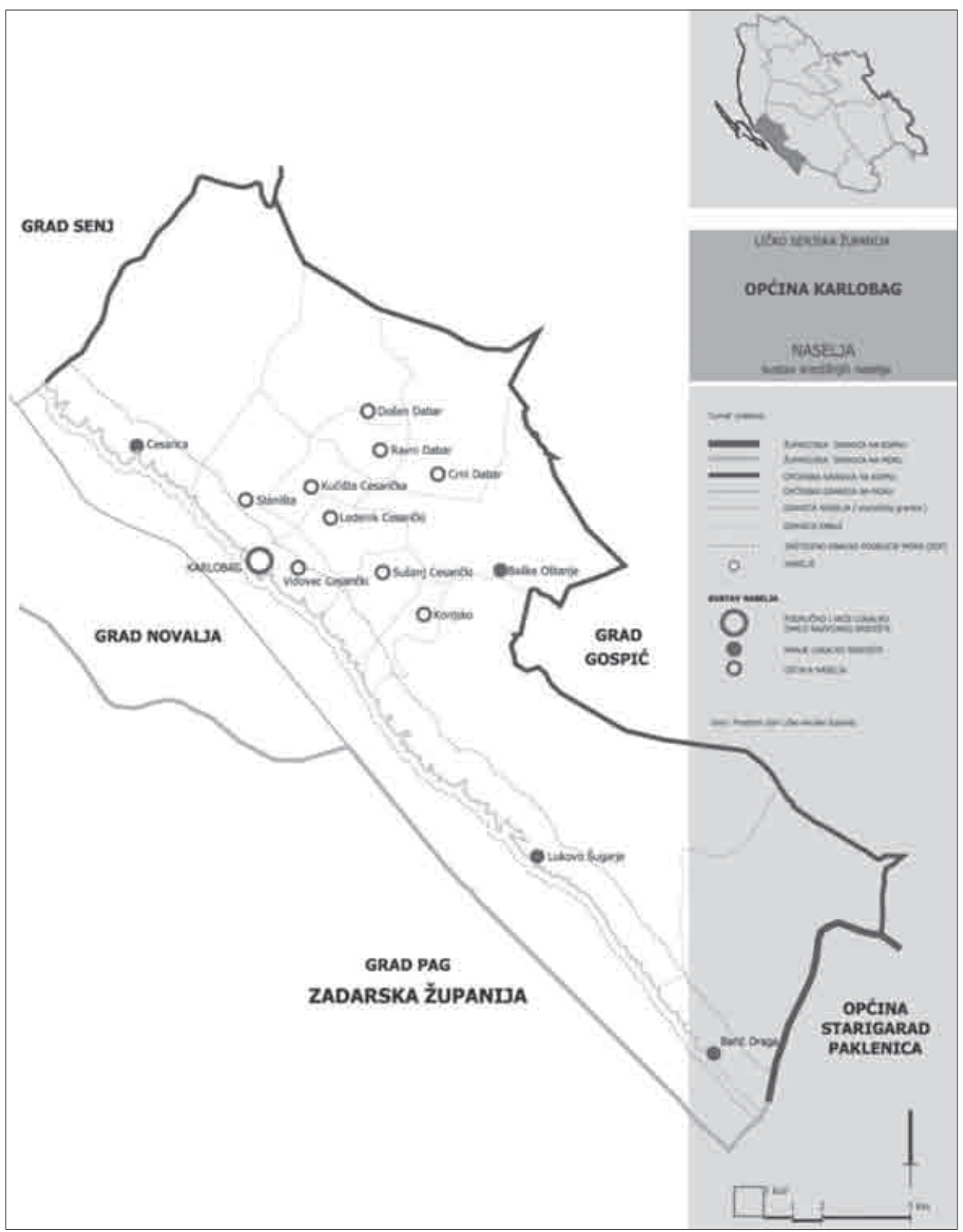

Karta 3. Općina Karlobag - sustav naselja, izvor: Općina Karlobag - izvješće o stanju u prostoru za razdoblje od 2010. do 2014. godine (neobjavljeno), 9. 
Tablica 1. Broj turističkih kreveta u Gradu Senju i Općini Karlobag prema podacima nadležnih turističkih zajednica.

\begin{tabular}{|c|c|c|c|c|c|}
\hline \multicolumn{6}{|c|}{ GRAD SENJ } \\
\hline 1. & Bunica & T3 & 2,0 ha & 180 korisnika & izgrađeno \\
\hline 2. & Spasovac & $\mathrm{T} 1$ & $1,3 \mathrm{ha}$ & 230 kreveta & neizgrađeno \\
\hline 3. & Ujča & T3 & 0,33 ha & 100 korisnika & izgrađeno \\
\hline 4. & Kalić & $\mathrm{T} 1, \mathrm{~T} 2$ & 4,80 ha & 500 kreveta & djelomično izgrađeno \\
\hline 5. & Jablanova & $\mathrm{T} 1, \mathrm{~T} 2$ & 6,2 ha & 380 kreveta & neizgrađeno \\
\hline 6. & Rača & T1, T3 & 2,5 ha & 300 kreveta/korisnika & izgrađeno \\
\hline 7. & Žrnovnica & $\mathrm{T} 1, \mathrm{~T} 2$ & 8,7 ha & 570 kreveta & djelomično izgrađeno \\
\hline 8. & Zidine & $\mathrm{T} 1$ & $13,2 \mathrm{ha}$ & 1000 kreveta & neizgrađeno \\
\hline 9. & Lukovo-Zala & T2, T3 & 3,1 ha & 100 kreveta & neizgrađeno \\
\hline 10. & Rastovača & $\mathrm{T} 1, \mathrm{~T} 2$ & 3,8 ha & 230 kreveta & neizgrađeno \\
\hline 11. & Lomivrat, Javorina & $\mathrm{T} 1, \mathrm{~T} 2$ & 10,0 ha & 800 kreveta & neizgrađeno \\
\hline \multicolumn{6}{|c|}{ OPĆINA KARLOBAG } \\
\hline 1. & Paški Porat & $\mathrm{T} 1, \mathrm{~T} 2$ & 17,0 ha & 1700 kreveta & neizgrađeno \\
\hline 2. & Gaj & T3 & 4,0 ha & 400 korisnika & neizgrađeno \\
\hline 3. & Karlobag & T3 & $1,5 \mathrm{ha}$ & 150 korisnika & neizgrađeno \\
\hline
\end{tabular}

Značajna je pojava zona ugostiteljsko-turističke namjene unutar građevinskih područja naselja pa tako u naselju Cesarica ona čini $20 \%$ od ukupnog građevinskog područja naselja.

Naselje Jablanac u Gradu Senju, i još neka druga koja posjeduju značajnije građevinsko područje, a mali broj stanovnika, imaju znatan turistički potencijal koji se može ostvariti kroz projekt i proces urbane sanacije.

Poljoprivredno zemljište, naročito osobito vrijedno obradivo tlo, odnosno vrijedno obradivo tlo, vrijedan je prirodni i gospodarski resurs koji je prije svega potrebno čuvati od prenamjene, a zatim ga aktivno koristiti.

Iz Izvješća je vidljivo kako su poljoprivredne površine u Gradu Senju vrlo male (čine svega $7 \%$ površine Grada), odnosno vrijedno, dakle upotrebivo 
poljoprivredno tlo čini svega 1,63\% površine Grada, a te su površine raspoređene uglavnom na području naselja Krasno, Vratnik i Melnice na Velebitskom padinama, dok je u Općini Karlobag taj postotak daleko manji (oko 0,6\% površine) i raspoređene su na prostoru Ledenika i Dabara.

Specifične prirodne pogodnosti za razvoj stočarstva omogućile su formiranje stalnih naselja na padinama Velebita u ljetnim stanovima za ispašu stoke (na visinama između 700 i 1000 m). Ovakav tradicionalni način života danas je skoro potpuno nestao, jer manja obiteljska gospodarstva održavaju tek pojedini uzgajivači, što je rezultiralo općim opadanjem broja stoke.

Na području Grada Senja ima 519,09 ha krških pašnjaka te 114,51 ha livada na koji su registrirani za korištenje i pogodni su za uzgoj ovaca. Postoje povijesni podatci o velikim potencijalima planinskih pašnjaka za razvoj stočarstva (o čemu svjedoče ostaci pastirskih stanova).

Na području Općine Karlobag prema podatcima Hrvatskog stočarskog centra ima oko 300 ovaca pasmine "domaća pramenka" i 2500 do 3000 koza koje drži dvadesetak uzgajivača.

Prostor Podgorja zbog svoje raznolikosti i područja mediteranske i planinske klime idealan je za razvoj pčelarstva i proizvodnju kvalitetnih vrsta meda (o tomu svjedoči broj uspješnih proizvođača meda). Na cjelokupnom području Grada Senja aktivno djeluje nešto više od 80 pčelara, dok je na području Općine Karlobag ta djelatnost više ekstenzivna a postoji svega nekoliko uzgajivača s ukupno dvjestotinjak košnica.

Načelno je u Prostornom planu Županije predviđeno nekoliko lokacija za marikulturu koje su proizišle iz Studije razvoja marikulture u Velebitskom kanalu, ali ni jednoj od lokacija nije dodijeljena koncesija što svjedoči o malom interesu za tu djelatnost, pa bi trebalo pronaći mogućnosti i potaknuti razvoj ove djelatnosti koja je itekako značajna za razvoj turizma.

U Gradu Senju 2014. godine bilo zaposleno 29 djelatnika u ribarstvu, u Općini Karlobag je taj broj neznatan .

Što se tiče razvoja marikulture, sve je uglavnom ostalo na planovima i ispitivanju pogodnosti područja za uzgoj školjaka. Koncepcija razvoja marikulture vezana je na kavezni uzgoj u akvatoriju većih dubina i dalje od obale.

Cijeli prostor Podgorja pripada Parku prirode Velebit, pa je gospodarska djelatnost korištenja mineralne sirovine "kamenolomi" ograničena na zadovoljavanje minimalnih potreba Hrvatskih šuma i Parka prirode.

Hrvatske šume su gotovo sva svoja eksploatacijska područja zatvorile i "sanirale". 
Važećim Prostornim planom uređenja Grada Senja i Općine Karlobag nisu predviđeni novi prostori za iskorištavanje mineralnih sirovina.

Značaj šuma nije samo u izravnoj gospodarsko koristi, već i u posrednim koristima kao što su pročišćavanje onečišćenoga zraka, usklađivanje režima i stanja voda, zaštita od erozije, bujica i poplava, zaštita od buke, pogodnost za rekreaciju i zdravstveni turizam.

Ekološka vrijednost šume danas višestruko premašuje njezinu sirovinsku vrijednost, stoga treba jačati ekološke činitelje održivoga gospodarenja šumama.

Preko 60\% površine i Grada Senja i Općine Karlobag pokriveno je šumom i značajan je gospodarski resurs ovog prostora. Iseljavanjem stanovništva s područja Podgorja, znatno je smanjen i broj ovaca i koza koje je stanovništvo uzgajalo na ovim područjima, pa je tako ozelenjela i inače kamenita-bijela primorska strana Velebita.

\section{Promet}

Autocesta Zagreb-Split, kao i planirana transeuropska željeznička pruga koja ide istim koridorom, u budućnosti će postati okosnica razvoja cijele županije. Značaj ovih europskih koridora velik je i za prostor Velebitskog podgorja. Nedostatci cestovne mreže na području Županije su kvaliteta i sigurnost postojećih cesta te usklađenost s europskim standardima, kao i nedostatna pokrivenost nekih područja.

Druga značajka geoprometnog položaja Ličko-senjske županije je veza kopna i otoka pomorskim prometom. Željeznički promet nema poseban značaj za ovaj prostor osim što planirana trasa buduće pruge tangira područje Grada Senja. Pomorski promet određen je na području Senja lukama županijskog značaja: Senj, Jablanac, Prizna i Stinica, zatim lukama lokalnog značaja: Sv. Juraj, Donja Klada, Starigrad; Lukovo i Krivača te plovnim putovima SenjBaška, Jablanac-Otok Rab, Prizna-Žigljen (Stara Novalja).

Na području općine Karlobag nalazi se pet morskih luka otvorenih za javni promet, koje su razvrstane prema značaju u županijske i lokalne. Luka županijskog značaja je samo luka Karlobag, dok su luke lokalnog značaja: luka Lukovo Šugarje (u uvali Porat) - teretna luka, luka Cesarica i luka Barić Draga.

Sustav pomorskog prometa i puteva potrebno je kvalitetnije osmisliti kako bi se povezao morski i planinski turizam te omogućiti s usidrenih kruzera posjet Parku prirode i Nacionalnim parkovima. 


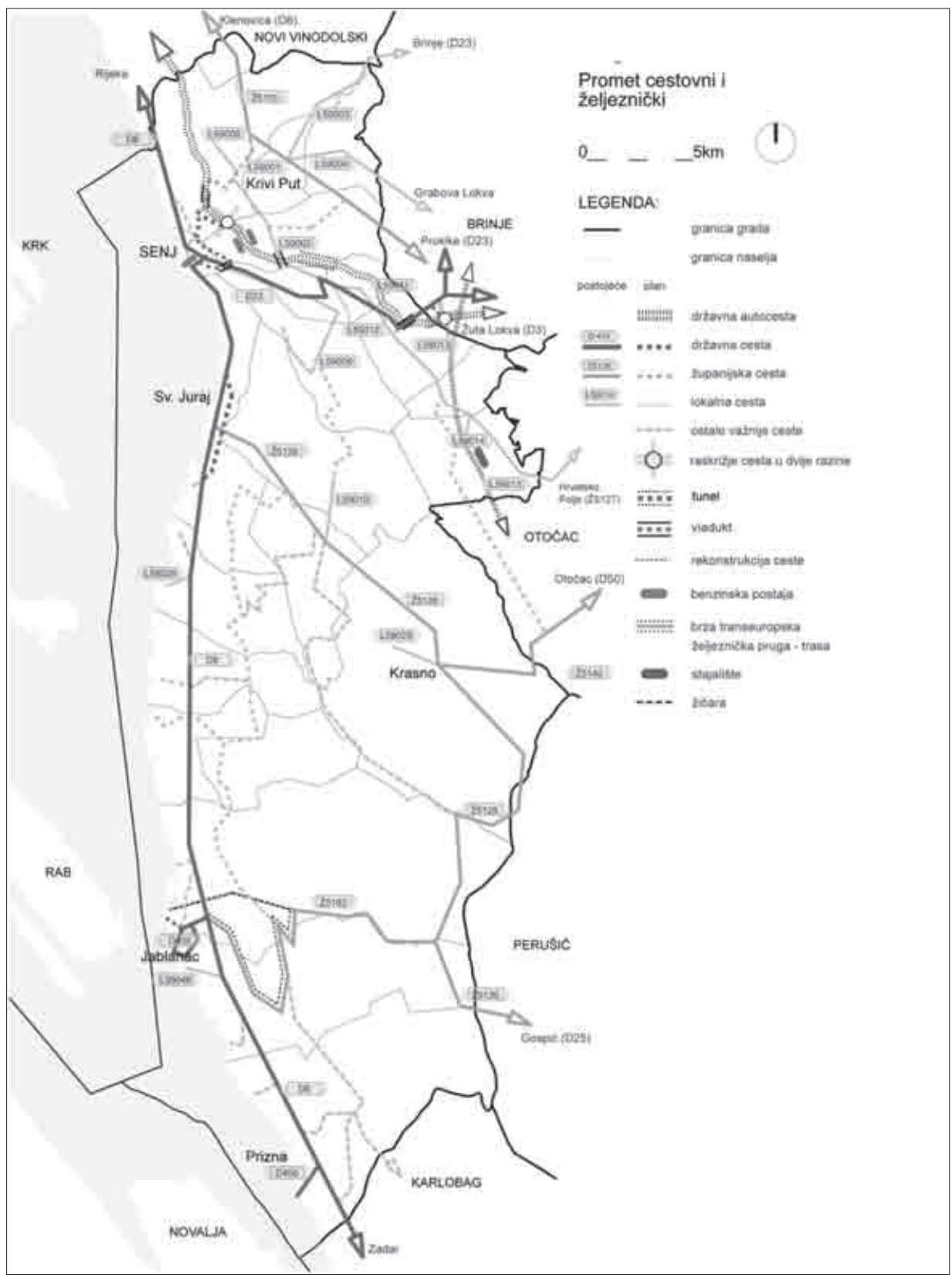

Karta 4. Prometni sustav Grada Senja, izvor: Službeni glasnik Grada Senja, br.1. od 26. veljače 2016, 53. 


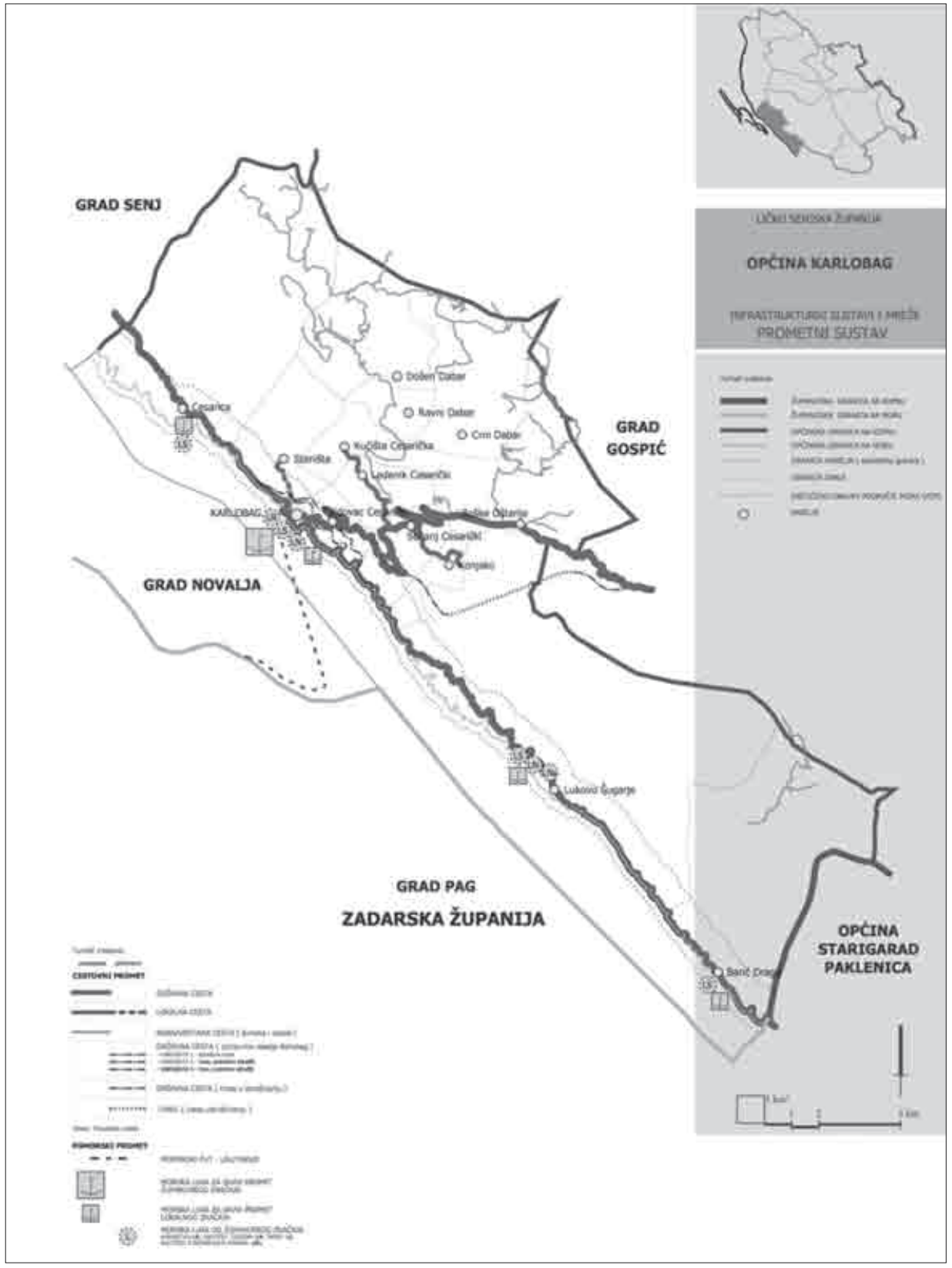

Karta 5. Prometni sustav Općine Karlobag, izvor: Općina Karlobag-izvješće o stanju u prostoru za razdoblje od 2010. do 2014. godine (neobjavljeno), 24. 
U sastavu operativne jedinice Senj nalazi se deset poštanskih ureda $\mathrm{u}$ sljedećim mjestima: Senj, Krivi Put, Vratnik, Krasno, Sveti Juraj, Lukovo, Starigrad, Jablanac, Karlobag i Lukovo Šugarje.

Telekomunikacijski se promet odvija unutar Telekomunikacijskog centra Gospić koji omogućuje pružanje svih telekominikacijskih usluga na području Županije. Čvorno područje AXE-10 centrale Gospić obuhvaća 57 centrala, a medu njima se nalaze i centrale koje pokrivaju Senj i Karlobag.

Unutar područja Županije sagrađena je takoder infrastruktura koja podržava rad mobilnih telefonskih mreža, Za prostore izvan naseljenih mjesta - kvalitetno pokrivanje cestovnih prometnica i plovnih putova na unutarnjim vodama i čitavom akvatoriju.

\section{Komunalna infrastruktura i elektroenergetski sustav}

U Gradu Senju i Općini Karlobag komunalna infrastruktura i elektroenergetski sustav dijeli se u dvije osnovne skupine: Infrastruktura energetskog sektora i infrastruktura vodnogospodarskog sektora.

Na podrućju Podgorja samo uže područje naselja Senja ima ostvareno pouzdano dvostrano napajanje (20 kV mreža od Novog Vindolskog), kao i za naselje Krasno (od strane Otočca) i uže područje naselja Svetog Jurja (od Senja). Iako naselja južno od Svetog Jurja imaju također dvostrano napajanje, zbog posebno teških zemljopisno-klimatskih uvjeta (područje iznimno jake bure i povremene posolice uz istovremeno zatvaranje cesta i puteva do elektroenergetske mreže) imaju nešto nižu pouzdanost od prosjeka RH. Posebno je to izraženo na području južno od Jablanca prema Karlobagu.

Mreža niskog napona (nazivni napon $0.4 \mathrm{kV}$ ) te niskonaponski priključci stambenih i gospodarskih objekata Općine Karlobag napajaju se iz $20 \mathrm{kV}$ mreže preko 46 transformatorskih stanica naponske razine $20 / 0.4 \mathrm{kV}$.

Duž Velebitskog podgorja postoje samo futurističke naznake za plinoopskrbni sustav, ali uglavnom vezane za ukapljeni plin i LNG terminal na Krku.

Vodoopskrbni distribucijski sustavi mogli bi se podijeliti u nekoliko glavnih pravaca, i to: vodozahvat Hrmotine-Senj, vodozahvat Senjska Draga, vodoopskrba putem isporučitelja Vodovod-Južni ogranak Senj i vodoopskrba naselja Krasno preko isporučitelja Komunalac Otočac. Na području Općine Karlobag za vodoopskrbu služe izvori Velika Rudanka i Crno Vrilo koja se nalaze istočno od Baških Oštarija na koti 952 m n.v. jedno pored drugog. 


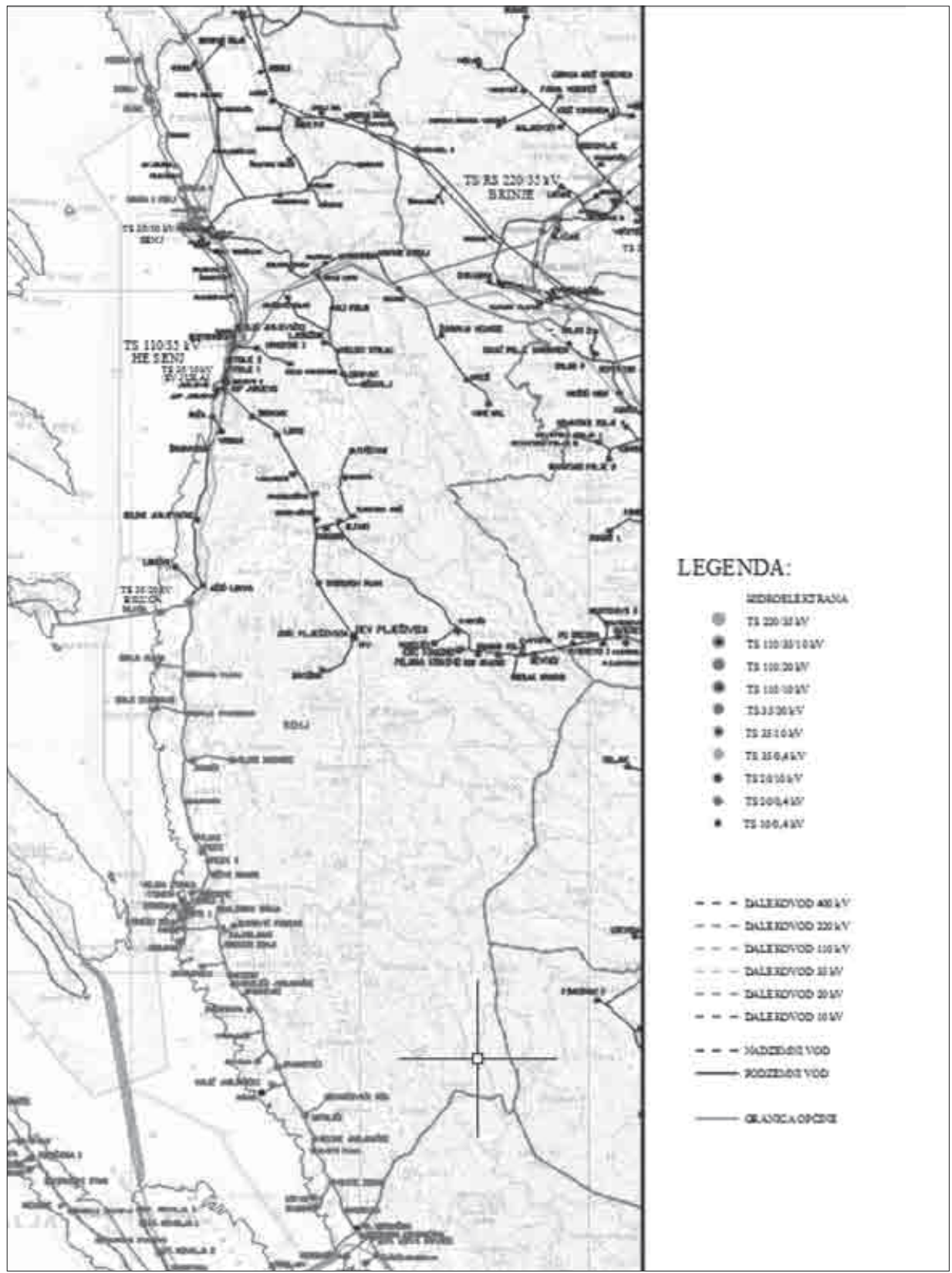

Karta 6. Elektroenergetska mreža Grada Senja, izvor: Službeni glasnik Grada Senja, br.1. od 26. veljače 2016, 59. 


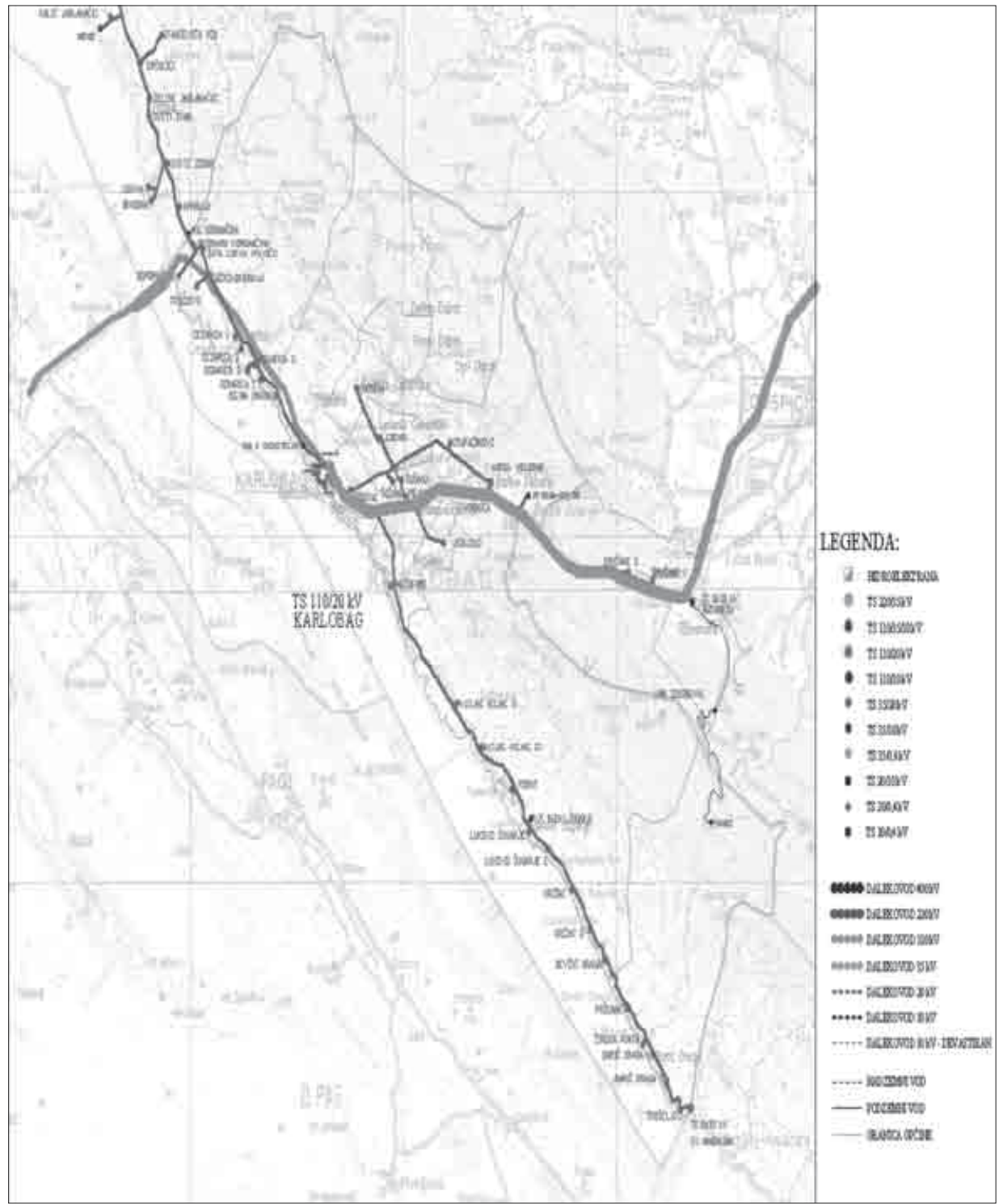

Karta 7. Elektroenergetska mreža Općina Karlobag, izvor: Općina Karlobag - izvješće o stanju u prostoru za razdoblje od 2010. do 2014. godine (neobjavljeno), 29. 


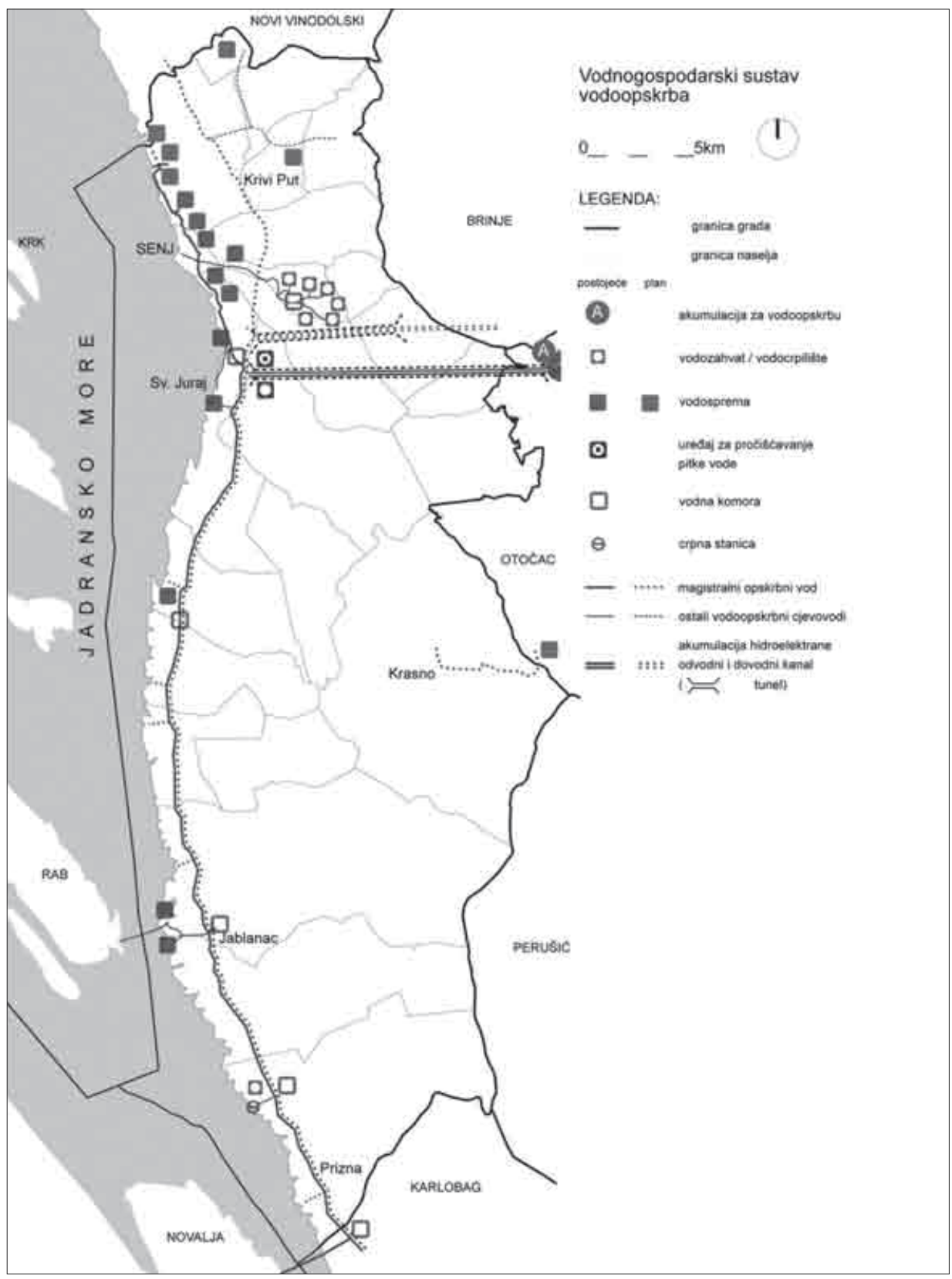

Karta 8. Vodnogospodarski sustav Grada Senja, izvor: Službeni glasnik Grada Senja, br.1. od 26. veljače 2016, 69 . 


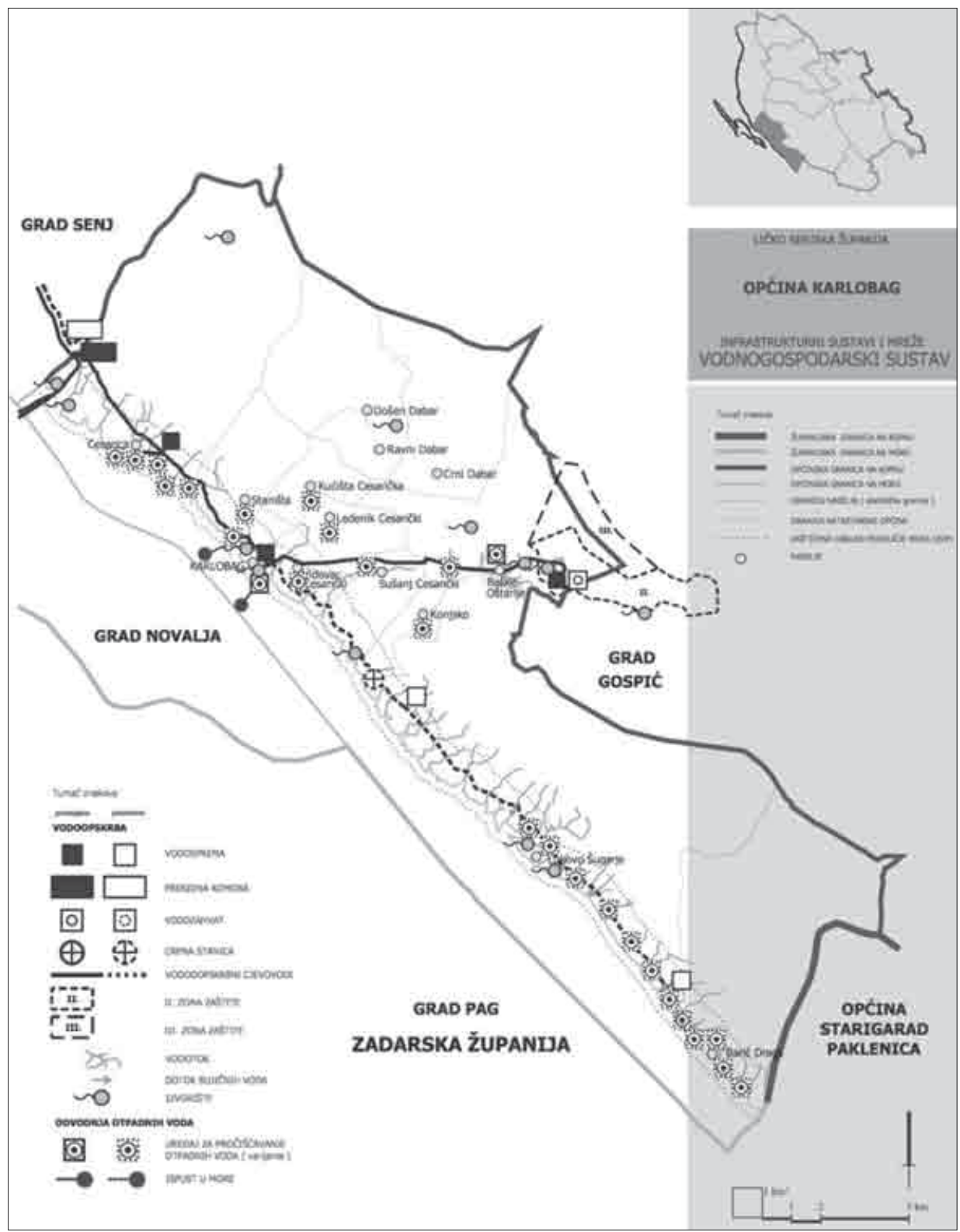

Karta 9. Vodnogospodarski sustav Općine Karlobag, izvor: Općina Karlobag - izvješće o stanju u prostoru za razdoblje od 2010. do 2014. godine (neobjavljeno), 33. 
Izvor je stalan s minimalnom izdašnošću 3 1/s do maksimalno 20 1/s za vrijeme većih oborina.

Izvor je kaptiran 1938. godine. Iz ovog izvora vrši se javna vodoopskrba za potrebe naselja Baške Oštarije te za područje Karlobaga. U Karlobagu se ovaj sustav spaja sa vodoopskrbnim sustavom Hrvatskog primorja - Južni ogranak iz Senja, odnosno iz vodozahvata Hrmotine.

Za Pag i Karlobag nedostaje 182 1/s. Taj manjak količine vode izaziva brzo pražnjenje P. K. Koromačina i nastanak zračnog udara u cjevovodu za Karlobag i podmorskom cijevima za otok Pag, što izaziva neželjene posljedice.U tijeku je izgradnja drugog cjevovoda od vodozahvata Hrmotine, ali je još daleko od granice Općine Karlobag.

Što se tiče odvodnje otpadnih voda Grad Senj ima izgađen prečistač i podmorski ispust, ali mrežu treba urediti, dok je za naselje Karlobag taj sustav u fazi realizacije.

Zaključak je da će za potrebe kvalitetnog budućeg razvoja te ekonomičnog i svrsishodnog korištenja sredstava u Županiji i u Podgorju biti potrebno:

- izgraditi cjelovite sustave odvodnje otpadnih voda,

- izgraditi sustave pročišćavanja otpadnih voda,

- utvrditi točne trase postojećih cjevovoda,

- datum izgradnje / revizije cjevovoda te

- izvršiti kontrolu stanja cijevi.

Može se reći da je odvodnja otpadnih voda predmetnog područja riješena u vrlo ograničenom opsegu te stoga postoji opasnost od mogućeg zagađenja okoline i negativnog utjecaja na podzemne tokove i priobalje. Potrebno je za sva naselja na obali izgraditi sustave odvodnje sanitarnih voda uz izgradnju uređaja za pročišćavanje i podmorske ispuste, te istražiti mogućnosti zbrinjavanja ostatnog mulja

\section{Zaštita i korištenje dijelova prostora od posebnog značaja}

\section{Zaštićeni dijelovi prirode-Grad Senj}

Cijeli prostor Općine Karlobag nalazi se u Parku prirode Velebit

Prirodne vrijednosti prostora koje pripadaju Gradu Senju su vrlo visoke. Natpolovični dio teritorija nalazi se u Parku prirode Velebit, a njegov sjeverni dio je proglašen Nacionalnim parkom "Sjeverni Velebit" za koji je izrađen PPPPO "Sjeverni Velebit". 


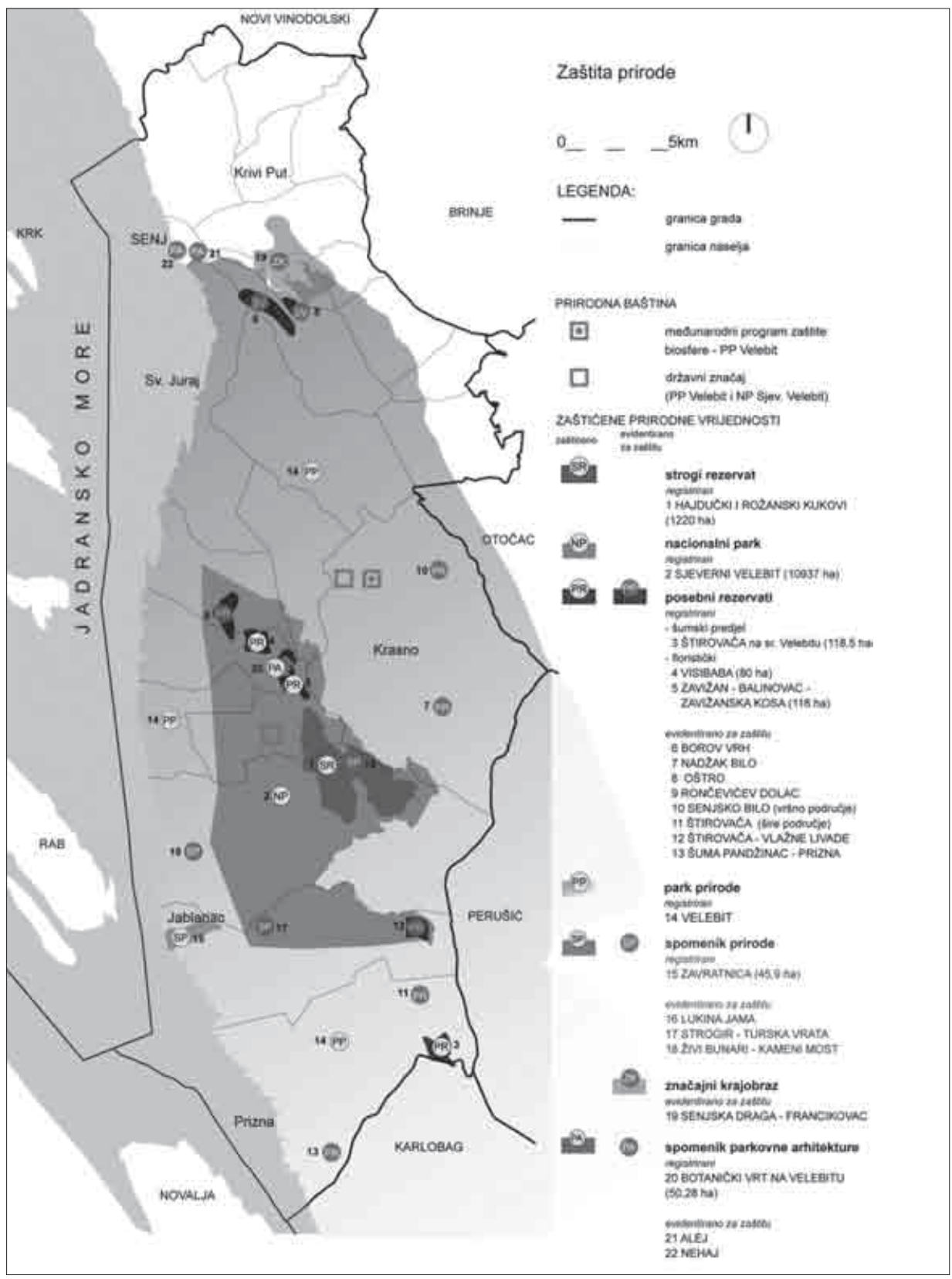

Karta 10. Zaštićena područja Grada Senja, izvor: Službeni glasnik Grada Senja, br.1. od 26. veljače 2016, 74 . 


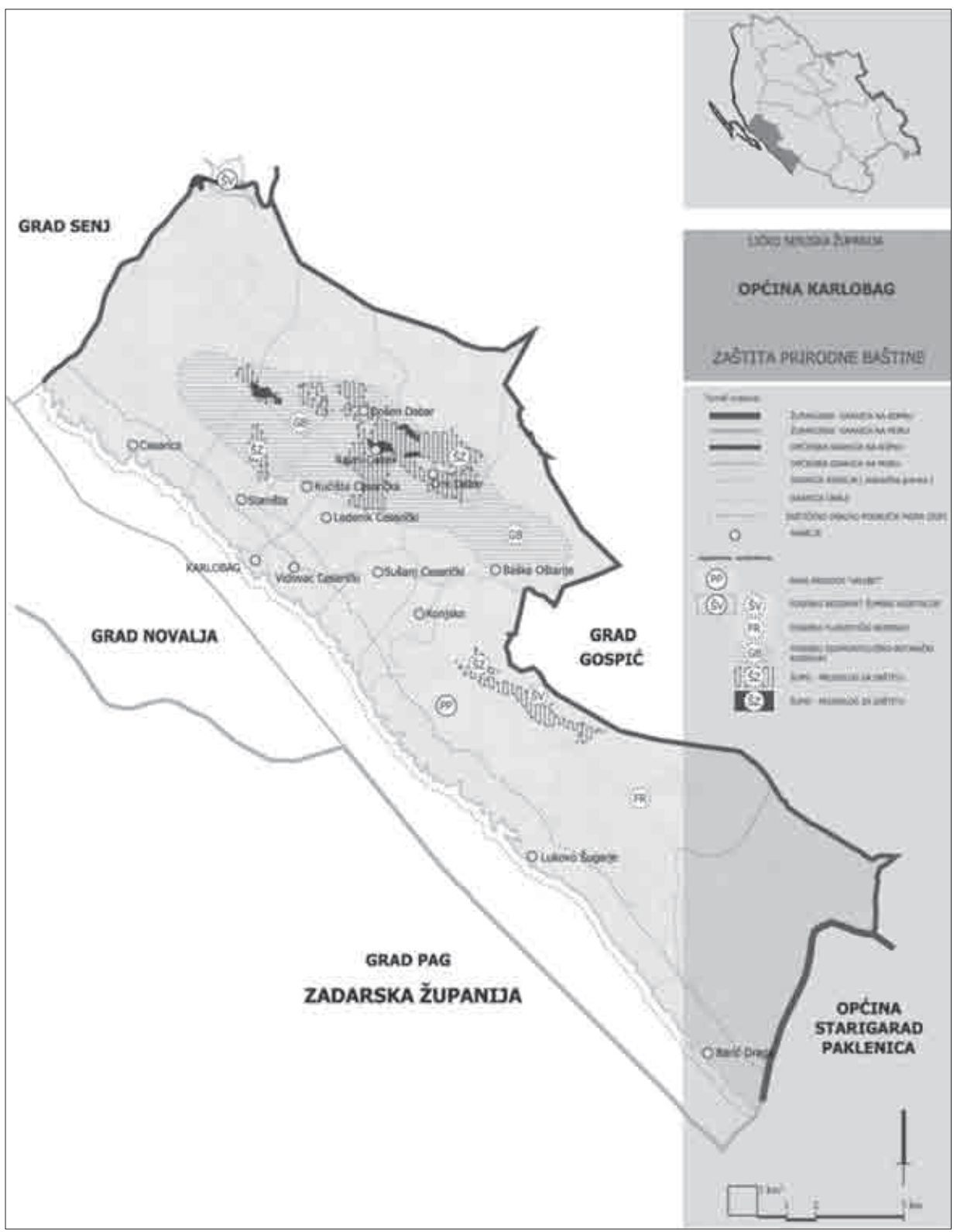

Karta 11. Zaštićena područja Općine Karlobag, izvor: Općina Karlobag - izvješće o stanju u prostoru za razdoblje od 2010. do 2014. godine (neobjavljeno), 36. 


\section{Kulturna baština}

Velebitsko podgorje, obalni dio područja Grada Senja, poznato je po vrijednom kulturno-povijesnom nasljeđu, dok je u Karlobagu registrirano stotinjak kulturnih dobara na području Općine, od čega je prema podatcima Konzervatorskog odjela registrirano svega osam što je manje od $10 \%$. U cijelom Podgorju evidentirana kulturna dobra, hidrološke zone-lokalitete, arheološke zone-lokalitete, povijesne cjeline, ruralne cjeline, sakralne spomenike, memorijalne spomenike, gradine, povijesna groblja, gospodarske objekte, mostove, bunare i česme, pastirska staništa, zone suhoziđa i povijesne komunikacije treba dodatno analizirati, a to bi se trebalo odraditi u okviru pripremnih radova za Prostorni plan Parka prirode Velebit.

\section{Obvezatni prostorni pokazatelji}

Naseljenost

Broj stanovnika u Županiji u međupopisnom razdoblju pao je za 2750 djelomično i zbog nove metodologije izračuna ukupnog broja stanovnika, što je za mali broj stanovnika Županije značajno smanjenje. Gustoća naseljenosti je pala s $10,3 \mathrm{st} . / \mathrm{km}^{2}$ na $9,52 \mathrm{st} . / \mathrm{km}^{2}$, što je znatno ispod prosjeka za Republiku Hrvatsku $\left(75,16 \mathrm{st} / \mathrm{km}^{2}\right)$. Ovaj problem daleko je izraženiji u Velebitskom Podgorju, a naročito na području Općine Karlobag.

Kao što se vidi iz tablica gustoća naseljenosti u Gradu Senju slična je kao i u Županiji, dok je u Općini Karlobag tri puta rjeđa (na ovom području imamo nekoliko naselja bez stanovnika, a nekoliko s deset stanovnika i ispod tog broja, što je izrazito zabrinjavajuće).

Tablica 2. Opća gustoća naseljenosti za Grad Senj u odnosu na LSŽ prema podatcima iz Državnog zavoda za statistiku, izvor: Službeni glasnik Grada Senja, br.1. od 26. veljače 2016., 69.

\begin{tabular}{|c|c|c|c|c|c|c|c|c|c|c|c|c|}
\hline \multirow{3}{*}{$\begin{array}{l}\text { Ličko- } \\
\text { senjska } \\
\text { županija }\end{array}$} & \multirow{2}{*}{\multicolumn{2}{|c|}{ Površina }} & \multirow{3}{*}{$\begin{array}{c}\text { Broj } \\
\text { naselja } \\
2011 .\end{array}$} & \multicolumn{6}{|c|}{ Broj stanovnika } & \multicolumn{3}{|c|}{ Gustoća naseljenosti } \\
\hline & & & & \multicolumn{2}{|c|}{1991.} & \multicolumn{2}{|c|}{2001.} & \multicolumn{2}{|c|}{2011.} & 1991. & 2001. & 2011. \\
\hline & $\mathrm{km}^{2}$ & $\%$ & & broj & $\%$ & broj & $\%$ & broj & $\%$ & & st. $/ \mathrm{km}^{2}$ & \\
\hline Županija & 5350,50 & 100 & 252 & 85.135 & 100 & 53.677 & 100 & 50.927 & 100 & 15,91 & 10,03 & 9,52 \\
\hline Grad Senj & 661,77 & 12,30 & 27 & 9205 & 10,81 & 8132 & 15,15 & 7.165 & 14,07 & 13,98 & 12,35 & 10,80 \\
\hline
\end{tabular}


Tablica 3. Opća gustoća naseljenosti za Općinu Karlobag s obzirom na ostale općine i LSŽ prema podatcima iz Državnog zavoda za statistiku. Izvor: Općina Karlobag izvješće o stanju u prostoru za razdoblje od 2010. do 2014. godine(neobjavljeno)., 40-41.

\begin{tabular}{|c|c|c|c|c|c|c|c|c|c|c|c|c|}
\hline \multirow{4}{*}{$\begin{array}{l}\text { Ličko- } \\
\text { senjska } \\
\text { županija } \\
\text { Županija }\end{array}$} & \multirow{2}{*}{\multicolumn{2}{|c|}{ Površina }} & \multirow{4}{*}{$\begin{array}{c}\text { Broj } \\
\text { naselja } \\
252\end{array}$} & \multicolumn{6}{|c|}{ Broj stanovnika } & \multicolumn{3}{|c|}{ Gustoća naseljenosti } \\
\hline & & & & \multicolumn{2}{|c|}{1991.} & \multicolumn{2}{|c|}{2001.} & \multicolumn{2}{|c|}{2011.} & 1991. & 2001. & 2011. \\
\hline & $\mathrm{km}^{2}$ & $\%$ & & broj & $\%$ & broj & $\%$ & broj & $\%$ & \multicolumn{3}{|c|}{ st. $/ \mathrm{km}^{2}$} \\
\hline & 5350,50 & 100 & & 85.135 & 100 & 53.677 & 100 & 50.927 & 100 & 15,91 & 10,03 & 9,52 \\
\hline $\begin{array}{l}\text { Općine } \\
\text { ukupno }\end{array}$ & 3095,58 & 57,86 & 146 & 34.616 & 40,66 & 18.819 & 35,06 & 17.559 & 34,48 & 11,18 & 6,08 & 5,67 \\
\hline $\begin{array}{l}\text { Općina } \\
\text { Karlobag }\end{array}$ & 283,37 & 5,30 & 14 & 1.039 & 1,22 & 1.019 & 1,90 & 917 & 1,8 & 3,67 & 3,60 & 3,24 \\
\hline
\end{tabular}

Životni standard - stanovanje

Graditeljstvo Grada Senja tradicionalno obilježava širenje Grada oko jezgre, a dijelom longitudinalno duž prometnica. Iako pretežito niska (jednokatna i dvokatna), nova obiteljska gradnja van jezgre je izrazitih urbanih obilježja. Višestambena gradnja je u posljednjih desetak godina obilježila područja pojedinih dijelova Grada. Smanjenje prosječne veličine domaćinstava s obzirom na članove (po domaćinstvu), pokazuje da je izmijenjen i način života. Ako se broj stanovnika Grada Senja po popisu iz 2011.g. podijeli s brojem stambenih jedinica, dobijemo 2,46 stanovnika po stambenoj jedinici.

Analizom broja stanovnika po popisu iz 2011.g. i broj stanova iz istog popisa pokazuje da svaki stanovnik Općine Karlobag ima gotovo tri stana, a svako domaćinstvo gotovo šest stanova. Iako statistički pokazatelji iz tablice upućuju na višak stambenog prostora, uvidom u stanje na terenu može se utvrditi kako dio stanovnika nema svoj stan, a u pitanju je i kakvoća stambenih jedinica.

\section{Opća demografska obilježja}

Opća demografska obilježja prostora Podgorja prema drugim dijelovima Ličko-senjske županije i Republike Hrvatske izrazito su nepovoljna, odnosno kako je već spomenuto Senj je unatoč povijesnoj i kulturnoj tradiciji najslabije naseljen grad u Ličko-senjskoj županiji, a vjerojatno i u Republici Hrvatskoj, a Općina Karlobag je najrijeđe naseljena općina. 
Stanovništvo

Ovo područje je izrazito slabo i disperzno naseljeno, depopulacijsko i emigracijsko područje. S takvim obilježjima ono je sa svim problemima koji iz svega toga proizlaze. Zato ovo područje treba imati status područja posebne državne skrbi.

\section{Opremljenost društvenom infrastrukturom (mreža i organiziranost)}

Dječji vrtići

Iako na prvi pogled broj djece u vrtićima u Senju i Karlobagu ostaje konstantan ili raste, onaj tko poznaje stvarno stanje zna kako je ta slika iskrivljena jer se djeca iz okolnih naselja, čiji roditelji rade u Senju i Karlobagu, upisuju u vrtić u centralnim naseljima jer nemaju alternativu.

Osnovne škole

Odgoj i obrazovanje djece na području grada Senja odvija se u jednoj osnovnoj osnovnoj školi čiji je osnivač Ličko-senjska županija.

U Općini Karlobag postoji osnovna škola samo u naselju Karlobag koju pohađa samo oko 40-ero djece u šest odjela (i taj je broj u opadanju), a za usporedbu valja navesti činjenicu kako je toliko djece bilo u prošlom stoljeću u osnovnoj školi u Baškim Oštarijama, što posebno svjedoči o padu broja stanovnika ovog područja.

Srednje škole

Srednju školu P. Rittera Vitezovića redovito pohađa 180 učenika u 12 razrednih odjela. Gledajući ukupno, postojeći kapacitet školskog prostora može primiti znatno veći broj djece.

Kultura

Što se tiče kulture, obrazovanja, sporta i rekreacije, još 1962. godine započeo je s radom Gradski muzej Senj, koji je i danas vrlo aktivan u kulturnom životu grada. Djelovanje Gradskog muzeja Senj ostvaruje se izlaganjem eksponata, preko novina, časopisa i stručnih edicija. U Senju djeluju Pučko otvoreno učilište Milutina Cihlara Nehajeva Senj koje organizira kulturne i obrazovne aktivnosti te Gradska knjižnica Senj.

U Općini Karlobag tijekom ljeta organizira se niz događanja u gradu Karlobagu, a na Baškim Oštarijama kroz cijelu godinu. 
Vjerske zajednice, manjine i civilne udruge

Ovo poglavlje obrađeno je kvalitetnije u drugim radovima u ovome tematskom broju Senjskog zobrnika, pa ovdje samo dajemo kratak izvod iz Izvješća. Od vjerskih zajednica na prostoru Ličko-senjske županije najzastupljenija je kršćanska zajednica u kojoj su najbrojniji katolici Župe u Gradu Senju pripadaju uglavnom Senjskom i Otočkom dekanatu, a župe u Općini Karlobag pripadaju Gospićkom dekanatu.

\section{Zdravstvena zaštita}

Radi razvoja i postizanja optimalne razine zdravstvenog sustava i skrbi u Ličko-senjskoj županiji vezano za Podgorje djeluju: Opća bolnica Gospić, Dom zdravlja Gospić s ambulantama u Karlobagu, Dom zdravlja Senj s ambulantama u Svetom Jurju i Krasnom te Zavod za hitnu medicinu Ličko-senjske županije sa Ispostavama u Senju.

\section{Socijalna skrb}

Okosnicu rada u djelatnosti socijalne skrbi na području Ličko-senjske županije čine centri za socijalnu skrb sa svojim podružnicama, tako za područje Senja postoji Centar za socijalnu skrb Senj, dok Karlobag pripada Centru za socijalnu skrb Gospić.

Pravosuđe

Na prostoru Ličko-senjske županije djeluju sudovi temeljem Zakona o područjima i sjedištima sudova (NN" br. 128/14) djeluju vezano za područje Senja i Karlobaga. Temeljem Zakona o područjima i sjedištima državnih odvjetništava ("NN" br.128/14) ustanovljena su županijska i općinska državna odvjetništava.

\section{Analiza izrade i provedbe dokumenata prostornog uređenja}

Kada govorimo o analizi izrade i provedbe sastavnica prostornog uređenja iz navedenih izvještaja, potrebno je pojasniti koja su to osnovna ograničenja, prioriteti, smjernice i buduća poboljšanja u mogućem i planiranom razvitku Podgorja.

$\mathrm{Na}$ prvom mjestu to su vidljiva ograničenja u prostoru. Sam raspored $\mathrm{u}$ prostoru planiranih površina s obzirom na vlasničku strukturu, prometnu povezanost, opremljenost komunalnom infrastrukturom, mogućnost i realnost 
realizacije, ograničenja iz mogućnosti gradnje zbog zaštite dijelova prirode, podzemnih voda i dr. Prostor u Parku prirode Velebit koji se preklapa sa zaštićenim obalnim pojasom mora također ograničava širenje zona predviđenih za izgradnju. Isto tako područja uz more već se u važećoj planskoj dokumentaciji štite kao zaštićeni obalni pojas, koji kao takav kroz ograničena širenja zona predviđenih za izgradnju i dalje treba čuvati od neadekvatne izgradnje (sporadični loši primjeri samo potvrđuju ovu tezu). Poljoprivredne površine naselja Krasno ,Ledenik - prostori malih polja i proplanaka kategorizirani su kao obradivo tlo i njega je planskim mjerama i odrednicama (sukladno i Zakonu o poljoprivrednom zemljištu) potrebno čuvati od neopravdanog širenja izgradnje, čuvati ga i kao krajobraznu odliku, ali i kao gospodarski resurs, iako su većinom karakterizirane kao ostalo obradivo tlo te ostale poljoprivredne površine, šume i šumsko zemljište, one se u jednakoj mjeri koriste i definiraju krajobraz.

Drugi važnan element u analizi jesu jasno artikulirani razvojni prioriteti, a to su u prvom redu kvalitetan sustav komunalne infrastrukture (opskrba energijom, opskrba pitkom vodom i sustav odvodnje otpadnih voda) te prometni sustav.

Od sustava komunalne infrastrukture ističe se sustav opskrbe primarno električnom energijom na kojeg će se sve više postavljati zahtjevi za fleksibilnošću o pitanju priključka zgrada i građevina u sklopu kojih su izvedeni lokalni manji sustavi korištenja obnovljivih izvora energije. Isto tako je važno što efikasnije izgraditi kvalitetniji vodoopskrbni sustav nad kojim će se moći sustavno obavljati kontrola. Prioritet zadržavanju statusa jednog od najčišćih krajeva u Hrvatskoj jest i kvalitetan sustav odvodnje otpadnih voda, posebice zato jer je riječ o geografski vrlo osjetljivom području. Naposlijetku, porebno je razvijati prometni sustav mreža koji bi uključivao razvoj lokalnog pomorskog prometa koji bi povezao obalna naselja te mreže biciklističkog prometa, ali za cjelokupni prostor - ne točkasto i sporadično, već sustavno.

Kada smo pojasnili koja su ograničenja a koji prioriteti, potrebno je dati razvojne smjernice za djelovanje koje moraju biti temeljene na jasno odabranim razvojnim prioritetima.

Smjernice za obje jedinice lokalne samouprave su uglavnom slične i nabrojene kako slijedi:

- Gospodarski impuls razvoja Područja koji će se temeljiti na prirodnim resursima, posebice šumama, a koji će poticati razvoj obrta $\mathrm{i}$ poduzetništva. 
- Održivi turizam temeljen na spoju morskog i planinskog koji koristi autohtonu poljoprivrednu proizvodnju u zaleđu.

- Središnje naselje Senj i Karlobag planiraju se graditi i uređivati sukladno funkcijama središnjeg naselja.

- U središnjim naseljima planira se uređenje građevinskog područja i područja za razvoj naselja, nove infrastrukture te opremanje gospodarskih zona.

- Poboljšati prometnu mrežu Područja koja povezuje sva veća naselja, a koju čine državne, županijske i lokalne ceste koja u svom tehničkom stanju nije zadovoljavajuća, poglavito zbog neadekvatnih križanja u naseljima. Prometne probleme Podgorja čini relativno loša povezanost obalnog prostora i planinskog zaleđa, kao i izlaz na autocestu ZagrebSplit.

- Prilikom izrade PPUO/G traži se obraćanje posebne pozornosti "krupnoj" infrastrukturi -određivanju koridora autocesta, čvorova na autocesti, pristupnih cesta, te vezano na te lokacije uslužnih objekata, gospodarskih zona i njihovo opremanje energetskom i drugom infrastrukturom, što je i učinjeno već u prvom PPUO/G, a kasnije kroz Izmjene i dopune PPUO/G uklanjani su nedostatci u ranijim planiranjima.

- Prostorno plansko rješavanje sanacije postojećih odlagališta komunalnog otpada, te konačno rješavanje zbrinjavanja otpada, što je kroz prostornoplansku dokumentaciju i učinjeno.

- Plansko rješavanje korištenja obnovljivih izvora energije te predlaže konkretno ugrađivanje u Prostorni plan istražnih prostora za vjetropark na prostoru Vrataruša i Pekin dolac (što je i učinjeno).

- Zbog izuzetne povijesne vrijednosti područja Podgorja treba obratiti posebnu pozornosti valorizaciji i zaštiti kulturne i prirodne baštine jer predstavljaju potencijal budućeg razvoja područja. Kvalitetno osiguranje prostora za razvoj društvenih, gospodarskih i ekoloških funkcija područja, sređivanje imovine jedinica lokalne samouprave i omogućavanje njihova dinamičnog razvoja .

Kako bi navedeni elementi bili primjenjivani, potrebno je poboljšati sam sustav prostornog planiranja počevši od izrade samih dokumenata prostornog planiranja koji bi morali biti vremenski definirani.

Kada govorimo o komunalnoj infrastrukturi, moramo napomenuti da je potrebno na nivou prikupljanja, analizi i vođenja stanja podataka o prostoru preporuka da se sustavno krene u utvrđivanje stanja i izradi kvalitetan katastar 


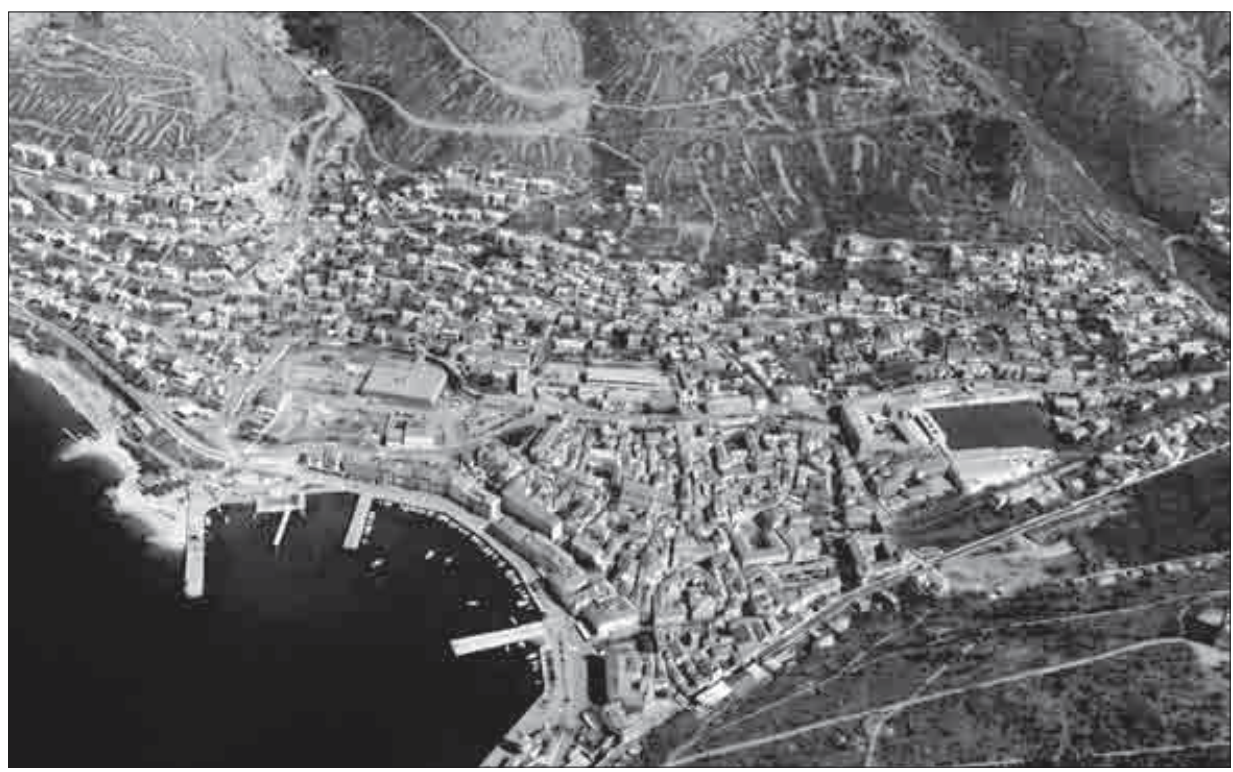

Sl. 1. Senj, foto V. Glavaš 2012.

vodova u cjelini na principima GIS-a (uz prethodno definiran i s nadležnim institucijama usklađen standard i metodologiju), jer je to osnova za daljnje kvalitetno i ekonomično upravljanje sustavom i troškovima.

Sustav odvodnje otpadnih voda također je potrebno u cjelini snimiti i izraditi katastar vodova koje treba izraditi na istim principima kao i spomenuti vodoopskrbni sustav. U okviru odvodnje potrebno je riješiti i problem pročišćavanja otpadnih voda i zbrinjavanja ostatnog mulja.

Stalni problem su i česta oštećenja mreže za elementarnih nepogoda odnosno orkanskih udara bure koji upućuju na potrebu uvođenja podzemnih vodova, odnosno zajedničko promišljanje Općine/Grada i HEP-a o rješenju tog problema.

Potrebno je o osmisliti lokalnu politiku (ili primijeniti dobru praksu drugih gradova i općina koji su navedeni problem kvalitetno riješili) o pitanju poticanja ugradnje opreme radi korištenja obnovljivih izvora energije primarno u funkciji umanjenja energetskih potreba zahvata i boljeg sumarnog učinka na okoliš.

Mjerama umanjenja naknada poticati ugradnju fotonaponskih elemenata na krovove velikogabaritnih zgrada - proizvodnih / poslovnih i drugih namjena. Izričito zahtijevati da se krovovi i/ili površine pročelja sportskih dvorana $u$ sklopu škola (ili druge velikogabaritne zgrade javne društvene namjene - 
vrtići) koriste i za postavu fotonaponskih elemenata, odnosno da se ugradnjom sustava korištenja i drugih oblika obnovljive energije (geotermalna energija) umanje dugoročno troškovi grijanja i hlađenja.

Jednako tako treba poticati ispitivanje plinoopskrbnog sustava, $\mathrm{i}$ to $\mathrm{u}$ kontekstu realizacije autoceste Rijeka - Žuta Lokva, ne samo kao cestovnog nego i kao infrastrukturnog koridora. Time će se još više opravdati otvaranje gospodarskih zona uz njega i omogućiti upotrebu alternativnih energenata za pokretanje proizvodnje.

Zatim, trebalo bi što prije izraditi prometnu studiju i u njoj analizirati i povezati pomorski i cestovni promet odnosno na drugi način proanalizirati kvalitetu vođenja svih vidova prometa kroz naselja - motornih vozila, biciklista i pješaka, utvrditi kritične točke te pokrenuti potrebne radnje za njihovo rješavanje (bilo kroz izradu potrebne projektne dokumentacije za potrebe uređenja, rekonstrukcije / izgradnje ili kroz korekciju prometne regulacije unutar postojećih prometnih površina). U ovome segmentu nikako ne bi smjeli zanemariti razvoj biciklističkog prometa jer bi on mogao biti značajnim element u razvoju turizma.

Kako bi se pokrenuli svi ovi spomenuti projekti treba izvršiti glavni preduvjet, tj. sređivanje prostorno-planske / projektne dokumentacije.

Općenito, prvi korak kao preduvjet mogućnosti realizacije zahvata u prostoru javnih sadržaja i provedbe dokumenata prostornog uređenja sukladno Odredbama Zakona o prostornom uređenju i gradnji (ako već nije) utvrditi zone naselja i pripadajuće cijene zemljišta za potrebe otkupa i uređenja javnih površina i za potrebe urbane komasacije i promjene oblika čestica u građevne čestice.

Od dokumenata prostornog uređenja koje će u narednom periodu biti potrebno napraviti jesu:

- Izmjene i dopune ili potpuno novi Prostorni plan uređenja Grada/Općine (PPUO/G)

- UPU zona određen u PPUO/G.

Projektnu dokumentacije za potrebe izgradnje komunalne infrastrukture i prometnica temeljiti na potrebama i planovima nadležnih službi i institucija. Osim toga potrebno je pripremiti i druge razvojne dokumente i programe (studije, istraživanja, razvojne koncepcije), i to: procjena ugroženosti stanovništva, plan zaštite i spašavanja i plan zaštite od požara.

Sve navedeno potrebno je koordinirati s Agencijom za poljoprivredno zemljište i prostornom bazom korištenja poljoprivrednog zemljišta (Arkod) radi poticanja gospodarskih aktivnosti kroz razvoj poljoprivrede. 


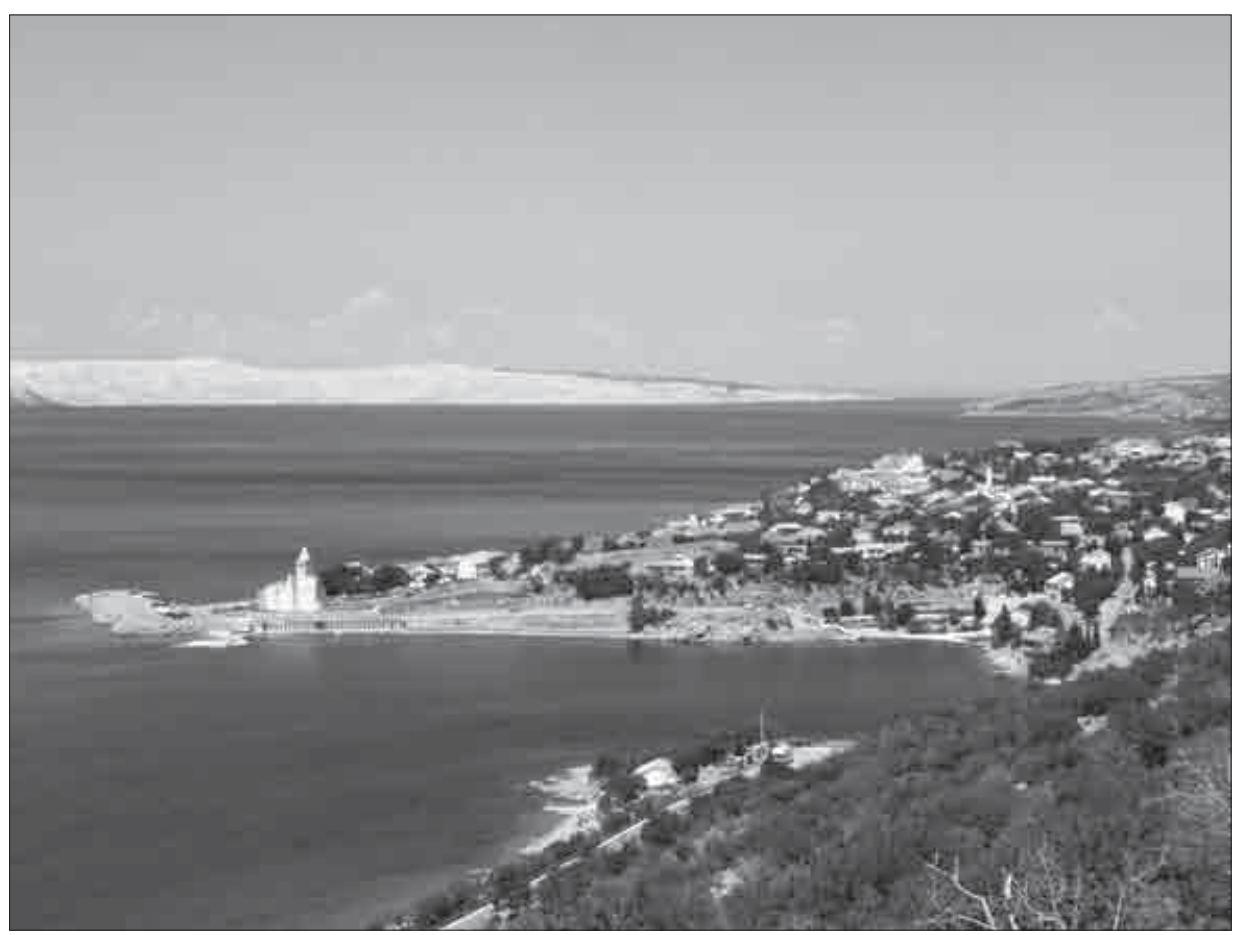

S1. 2. Karlobag, foto M. Glavičić 2013.

Za ovaj prostor posebno je dragocjen i značajan obalni pojas s kojim se mora integralno upravljati. Tako je potrebno dodatno analizirati ranjivost obalnog područja i osjetljivost na klimatske promjene te kvalitetnije odrediti namjenu mora. Uz more su turističke zone i naselja, naselja propadaju, a turističke zone se planiraju, ali se ne realiziraju; more je i izvor hrane, ali se na našem području slabo koristi. Ove zone trebale bi biti ujedinjene u ciljani razvoj održivog turizma tako da bi postojao jedan turistički klaster. O razvoju turizma u Podgorju pišu u ovom broju Senjskog zbornika kolegice Saša Poljanec Borić i Anita Bušljeta Tonković te kolega Nikola Šimunić.

\section{Zaključak}

U ovom radu se prezentiraju i analiziraju postojeća izvješća o stanju u prostoru Grada Senja i Općine Karlobag, čija područja su u koliziji s prostorom Podgorja i nalaze se u Ličko-senjskoj županiji. Jasno je da postoje brojni gospodarski, kulturni i razvojni potencijali koji nisu kvalitetno artikulirani 
u postojećim izvješćima, a mogu biti važan element u ponovnom razvoju kraja pod Velebitom. Jedan od najpotrebnijih aparata kako bi se postigli uređeniji i napredniji procesi u gospodarenju ovoga područja jest i stvaranje Informacijskog sustava prostornog uređenja u koji će biti pospremljeni (u slojevima) podatci o infrastrukturi, katastarski podatci, namjena, itd. Tako će temeljem uređenog Informacijskog sustava planerima biti omogućena lakša priprema boljih planskih rješenja i rano uočavanje zapreka za njihovu provedbu. Prostorno planiranje u ovome procesu ima središnju ulogu u kojoj moraju sudjelovati svi relevantni faktori koji su vezani uz ovo područje.

\section{Literatura}

Strategija prostornog uređenja Republike Hrvatske (1997.), (gl. ur. Matija Salaj), Zagreb:Ministarstvo prostornog uređenja, graditeljstva i stanovanja, Zavod za prostorno planiranje.

Izvješće o stanju u prostoru Grada Senja (2016.), Službeni glasnik Grada Senja, br.1., 26. veljače 2016., Senj, 24-352.

Izvješće o stanju u prostoru općine Karlobag za razdoblje od 2010. do 2014. godine(neobjavljeno) (2015.), Gospić, Zavod za prostorno planiranje Ličkosenjske županije, 1-61.

\section{FROM REPORTS ABOUT THE CONDITION IN THE AREA OF THE TOWN OF SENJ AND THE MUNICIPALITY OF KARLOBAG}

\section{Summary}

The paper is primarily based upon reports about the condition in the area, which provide the clearest assessment of the current condition, of the analysis of the spatial development and the development planning for the following period. It concerns reports for the town of Senj and the municipality of Karlobag. In the paper the author emphasises what the basic problems are, but also the defined comparative advantages in the planning of the observed region in the subVelebit channel. So, with the aid of such documents it is possible to plan and foresee a possible development which is based on the existing conditions.

Keywords: the town of Senj, spatial planning, condition in the area, municipality of Karlobag 